\title{
Human Rights Education: Form, Content and Controversy
}

\author{
Brian Orend \\ University of Waterloo
}

\begin{abstract}
Human rights education, in North America, is still developing and perhaps only in its adolescence. This is, on the one hand, quite shocking, given the foundational role such rights (supposedly) play in the core societal structures of the United States and Canada. On the other hand, the human rights movement has exploded world-wide since 1945 - rendering it in many ways a new normative world - and it is hard to think of other countries obviously doing better. To enable readers to draw comparative and intrinsic lessons, this paper examines both the form and content of human rights education in North America. The form section focuses on the modalities and availabilities of such education. The content section, by contrast, focuses on some of the "hot topics" and prominent dilemmas in contemporary North American human rights education. Emphasis is there placed on taking a principled, consistent stand in light of these latest controversies and challenges. In other words, and owing to the author's nature as a philosopher, the content section will feature arguments highlighting the strength of a certain way of viewing and teaching human rights in the face of doubts about them and challenges to them.
\end{abstract}

Key words: comparative human rights education; social institutions; human rights theory; universality; equality; justification.

\section{RESUMEN}

Este artículo tiene dos partes: examinar las modalidades y los tópicos actuales de la educación en derechos humanos en Norteamérica; y ofrecer argumentos informados para que los educadores en derechos humanos encaren los cambios filosóficos. En el curso de estas reflexiones, se establecen las siguientes propuestas: 1) hay una cuestión para avanzar en la educación en derechos humanos Norteamérica; 2) la educación en derechos humanos norteamericana es demasiado particular, centrada en la legislación nacional sobre las libertades civiles; 3) esta obsesión legal podría limitarse con una pedagogía que se centre en comprender la estructura básica y en no abusar tampoco con los estudiantes de las añejas distinciones entre derechos de primera y segunda generación; 4) las investigaciones más recientes enfatizan la vinculación entre los derechos humanos y sus instituciones, no sólo nacional sino internacionalmente a la luz de la globalización; 5) tenemos los recursos conceptuales para contrarrestar la equivocada atracción de los estudiantes por el relativismo ético y político y la postmodernidad; y 6) tenemos argumentos poderosos para resaltar la genuina universalidad y racionalidad de los derechos humanos y para cuestionar a los que piensan que los derechos humanos causan problemas a la seguridad nacional y a la cohesión social.

Descriptores: Educación comparada en derechos humanos; Instituciones sociales; Teoría de los derechos humanos; Universalidad; Igualdad; Justificación. 
RÉSUMÉ

Ce papier comprends deux parties: donner une vue d'ensemble des modalités et des questions brûlantes en matière d'education aux droits humains en Amérique du Nord; et presenter des arguments éclairants pour les éducateurs en droits humains face aux defis philosophiques communs. Au cours de ces réflexions nous affirmons les propositions suivantes: (1) en Amérique du Nord, il existe au niveau supérieur un problème d'accès à l'éducation aux droits humains; (2) l'éducation aux droits humains nord-américaine est trop introvertie et centres sur la legislation des libertés civiques domestiques; (3) une pédagogie par rapport à la comprehension de la structure de base pourrait remédier à cette obsession en matière légale et désillusionner les étudiants au sujet de distinctions entre les droits des premières et secondes générations; (4) la recherche la plus récente appuie une position holiste face aux droits humains et aux institutions associées, non seulement au niveau national mais aussi international, étant donné la globalisation; (5) nous avons les resources conceptuelles pour contrer l'attrait erroné des étudiants envers le relativisme éthique et politique et le post-modernisme; (6) nous avons des arguments puissants qui soutiennent l'universalité veritable et la rationnalité des droits humains, et qui démolissent les arguments qui présument que les droit humains sont cause de problèmes pour la sécurité nationale et la cohesion sociale.

Mots-cléfs: Éducation aux droits humains comparative; institutions sociales; la théorie des droits humains; L'universalité; l'égalité; la justification

\section{Form}

The norm in both the United States and Canada, regarding formal exposure to human rights education, is for very brief introductory "units" to be taught at the advanced primary school level (i.e., Grades 5-7) and usually again at the early secondary school level (i.e., Grades 9-10). These units, only a few hours in total, fail to have a consistent nesting: pending place and school board, one can find them in courses as diverse as "Civics and Social Studies" and "World Religions." Further study is sometimes possible at the advanced secondary school level (i.e., Grades 11-12) but then almost always only: 1) on a voluntary or optional basis; 2) at an advanced, pre-university level of study; and 3) in a law-related course, such as "The American [or Canadian] Legal System." 1 There are then post-secondary studies possible within human rights, but these are: 1) entirely voluntary; and 2) usually parts of advanced post-post-secondary programs within faculties of law, education, political science/international relations and health sciences.

It is fair to say that, outside such specialized second degree programs, permanent courses exclusively devoted to human rights at the general Bachelors' degree level are still very few and far between. For example, my university agreed to establish such a course only in 2003 - and it is a major mid-size university with an average annual enrolment of 20,000. In all of Canada, it is possible to receive a B.A. majoring in human rights at only two universities: Ottawa; and St. Thomas University in Fredericton, NB. In America, the story is the same in spite of the greater resources and population. A handful of small liberal arts colleges in New England mirror the Canadian programs but otherwise one essentially must wait until one's second degree to do intensive study of human rights - and then usually at a large, exclusive university. In terms of university-based human rights centres - i.e., advanced academic research centres whose exclusive purpose is the study of human rights - Ottawa and St. Thomas come up again in Canada, but closely related centres exist at Calgary and York. Just under 20 
U.S. universities have such centres - again, essentially an identical proportion to Canada - but they are all affiliated with strong, prominent, urban law schools. ${ }^{2}$

Most human rights professionals, of course, find this quantum of North American human rights education insufficient - perhaps even appallingly so. They all note the irony between the pro-rights self-image both countries have of themselves and the spotty, minimalist record both have regarding human rights education for their own citizenry. To the extent to which both nations, within their foreign policy and development aid programs, put strong emphasis on human rights education within the developing world, ${ }^{3}$ one would think they would practice a little more heavily what they preach.

These criticisms are accurate, but they are also easy to make. Curricular reforms, we know, can take a long time. And - at the primary and secondary levels, especially there are so many things to cover that one is never going to satisfy everybody, particularly professionals in a given field. There are only so many resources to go around within school systems: every agenda competes for the attention of the same taxpayer. What is so wrong, in the final analysis, with providing a general introduction, and then leaving more details up to the interests of the students? The real issue is: what is a fair standard for making judgments in this regard? If the standard is not being hypocritical in foreign aid, or the more demanding (utopian?) ideals of the human rights professional, then these programs do not appear so lovely. If the standard, by contrast, is the more realistic or pragmatic one of comparing current achievements to the past, then things don't look nearly so bad - indeed, one can even discern clear progress.

Thirty years ago in North America, there were exactly zero human rights research centres and undergraduate programs ... and the Canadian Charter of Rights and Freedoms did not even exist. The term "human rights professional" would have baffled any within ear-shot, and so on. The best standard, of course, is probably half-way between these two: not so low that current practice seems perfection; not so high we have no hope of attaining it given finite time and resources. There is room for improvements, both in quality and quantity. One option, at any of the levels, might be to partner for a "unit" with the increasing number of human rights non-governmental organizations (NGOs). Many of the larger ones now themselves offer educational seminars of their own and these are often staffed by front-line human rights professionals who have been to war zones, refugee camps, AIDS hospices, military tribunals, et cetera. ${ }^{4}$ Another chance for improvement exists in terms of access to advanced human rights education. One's opportunities to receive this truly plummet in North America unless one is enrolled full-time in an expensive, large urban university with a law school. Ways to improve this include, for instance, distance education offerings. We must be vigilant that human rights education and practice not become (remain?) a surprisingly small and elite world, dominated by big-city lawyers, government officials, academics and NGOs. Such a reality runs against the grain of the universality and equality intrinsic to human rights themselves.

One major, and fair, criticism of current North American human rights education is that much of it - emphatically so at the primary and secondary levels - is "inwarddirected", i.e., focussed on domestic or national civil liberties legislation. (This bias is also reflected in advanced research, wherein domestic law-related issues attract much 
more state funding than any other identifiable topic within human rights. $)^{5}$ Exposure to core domestic human rights documents, such as the U.S. Bill of Rights and the Canadian Charter, is an integral part of the status quo. While it is certainly understandable that school systems wish to acquaint their own residents with local legal liberties, this domestic law emphasis does come at the price of two major negatives: 1) the underemphasis on international human rights, and the related issue of what responsibilities wealthy nations might have towards the global poor; ${ }^{6}$ and 2) the over-emphasis on the law as the main or only institution responsible for human rights fulfilment. This second point in particular merits further discussion.

\subsection{Law and The Basic Structure}

The law remains, undeniably, a vital sphere for human rights definition and protection. Lawyers have made some of the most meaningful contributions to the ongoing struggle for human rights realization. But the law does not deserve the canonical position it is given in contemporary North American human rights education. This position not only comes from practicality and the power of lawyers but also because of an incomplete conception of human rights and what it means to satisfy them. We witness this incompleteness when we reflect on the phenomenon of "trophy law."

"Trophy law" refers to a glowing piece of legislation which, unfortunately, bears absolutely no resemblance to the facts on the ground - it is merely a showpiece without any substance. Trophy law shows that, when we talk about realizing human rights, we must be talking about more than merely drafting a bill or charter, and then passing it into law. The law must be effectively enforced. Police officers and the courts must take the law seriously. Indeed, resources must be found to pay for police officers and judges in the first place, and such officials need clear direction from the government that it makes respect for rights a top priority. So we begin to see that the realization of human rights does not just involve the legal system but also the political system and the resources of the economy. And how are all these politicians, bureaucrats, judges and police officers going to take rights seriously unless they have been properly educated about, and inspired by, them in the first place? At some point, even the education system gets fundamentally implicated in human rights satisfaction in a given society.

Human rights are general moral rights which every human being has by reason of elemental ethical entitlement, regardless of whether this gets officially recognized by various governments. Human rights are high-priority justified claims we all have to those things we both vitally need and which we can reasonably demand as a matter of minimally decent treatment. ' Which objects are these? As I have argued elsewhere, the most basic and important set of human rights objects are "the foundational five": physical security; material subsistence; personal freedom; elemental equality; and social recognition as a person and rights-holder. ${ }^{8}$ From this abstract list of five, we then reflect more concretely on what each value implies - given human nature, available resources and the kind of society we are trying to build. We arrive at a reasonably full listing of human rights objects, and in my view the United Nations' Universal Declaration on Human Rights (UDHR) offers as good a list as any other document. ${ }^{9}$ 
What does it mean to satisfy or realize human rights, thus defined? Clearly, the trophy law approach is nowhere near enough. Human rights are realized when everyone actually possesses the objects of their human rights: physical security, material subsistence, personal freedom, elemental equality and social recognition. The law alone cannot provide all this. How do we achieve this, then? We achieve it by shaping the basic structure of society in the appropriate manner. What is the basic structure?

The basic structure is a concept coined by John Rawls, refined by Thomas Pogge, and drawing heavily on American social science and European political theory. ${ }^{10}$ The basic structure, Pogge says, is composed of "the largely constitutive ground-rules that shape society." The basic structure contains the most fundamental and influential terms of social cooperation. Usually, these constitutive ground-rules call for the construction of certain institutions to guide and shape society. The institutions make the rules real: the abstract values, interests and principles which govern society are given concrete embodiment, and the embodiment in turn realizes and reinforces the interests and principles. How the basic structure is put together comes, over time, to exert effects on society's members which are "profound, pervasive, inescapable and present from birth." "11 The idea is this: the most important social institutions shape the overall social conditions within which we live our lives. Which social institutions we select and staff, the kind of institutions we allow to take root and operate, end up shaping the significant aggregate features of our shared social landscape. The institutions do not literally determine us, of course, but they do exert profound influence over the social context in which we freely make our choices and forge lives for ourselves.

Which specific social institutions count as part of the basic structure of a given society? Consider the following:

1. The mode of economic organization in the society. For example, do free markets exist, or is the economy centrally planned? How are goods produced and then distributed? Is money or barter the means of exchange? What is the level of taxation, and how is the tax burden distributed? Are people allowed to hold private property?

2. The mode of political organization in the society. How is government established and operated? Who decides who rules, and what powers are the rulers given? Is it a democracy? How is the civil service staffed: through patronage or merit? Is there a division of power? Into which fields of human endeavour does government intervene?

3. The mode of legal organization in the society. Is there an effective written constitution? Is the judiciary separate and independent from other branches of government? Are judges appointed or elected, and are they efficient and non-corrupt? Do judges or juries of peers try cases? What legal rights do citizens have? Can people appeal legal decisions to a different level of court?

4. The mode of deploying armed force in the society. How is law and order secured? How are police officers recruited and trained? When are they allowed to use force? When are people thrown, and kept, in jail? Do civilian authorities exercise ultimate control of the police? How does the society defend itself? What level of defence spending is present? When does the society deploy its army, navy or air force? 
5. The mode of delivering health care and education in the society. Are basic levels of health care and education guaranteed to everyone? What are the measurable "outcomes" regarding health levels and educational attainment? What is taught at school - e.g., are human rights taught? Who gets into college or university, and why? How are hospitals funded? How are drugs and medicines produced and distributed?

6. The mode of family association acknowledged in the society. Is marriage encouraged, and divorce allowed? What rights do parents have over their children, and which duties do they owe them? What claims do the spouses have on each other? Are same-sex marriages permitted? How are family groupings treated by tax and other authorities?

How a society answers the questions under each of these six headings will, obviously, come to exert a "profound, pervasive and inescapable influence" over its members. The crucial thing is this: how a society shapes these institutions will have enormous effect on the realization of human rights in that country. The law is one of these institutions but clearly is not the only one. Human rights education in North America would be vastly improved if we adopted this more complete and sophisticated understanding of the social world, and how values come to be realized - or else violated - within it. The key is not the law; it is how the whole package of core institutions fits together.

\subsection{Holism and The Five Principles}

This conclusion is buttressed by the latest social science research into international development. Economists Amartya Sen and Hernando de Soto ${ }^{12}$ have stressed the holistic approach, which not only reveals the narrowness of how most of us have taught human rights but also the incorrectness of a traditional distinction in human rights discourse, namely, that between civil and political rights and socio-economic rights. The former, also called "first generation rights", involve claims to security of the person, property, due process and standard political and social liberties, such as freedom of speech and religion. The latter, also called "second generation rights", involve claims to things like subsistence income, general education and basic health care. This distinction - unfortunately rendered into international law ${ }^{13}$ - cannot be sustained because, as the two economists show, progress on socio-economics presupposes a stable set of civil and political rights (to property, contractual freedom and due process in particular). And such a stable set requires a large and continuing socio-economic investment. It is a synergistic process of mutual dependence between the two "separate" concerns. ${ }^{14}$ Thus, the very latest research stresses how human rights support each other and form a coherent whole - and, in turn, demand a comprehensive and interlocking set of institutions and, where needed, institutional reforms. Indeed, this research ${ }^{15}$ shows that most societies with reasonable realization of human rights sport consensus regarding five principles:

- First, a shared moral culture that enshrines respect for the worth of each person. Simply providing a decent moral education, which develops a sense of basic humanity can go a long way towards developing a rights-respecting culture. 
- Secondly, rights-respecting societies allow people, in the first instance, the freedom and opportunity to secure the objects of their human rights for themselves. Most people, given the chance, will be able to find for themselves the means needed to live a minimally good life.

- Third, such societies are ruled by law and order, providing a social context secure enough that it makes sense for people to strive after what they want, not having to worry constantly about the security of themselves and their possessions. Human rights violations, moreover, get punished.

- Fourth, rights-respecting societies make it clear that the provision of human rights objects will be available only to those who genuinely cannot provide for themselves. This is a reasonable measure to take to reign in costs, since it sends out the appropriate incentives in favour of self-reliance yet it is also humane in guaranteeing to the unfortunate that they will not be left to fall below the minimally decent standard of living denoted by human rights. This implies the presence of some social security assistance in the midst of an otherwise free society that allows and rewards effort and industry.

- The fifth aspect is institutional accountability. Since social institutions play such an important role regarding whether or not people enjoy the objects of their human rights, it follows that there must be some mechanism for holding them accountable for fulfilling that function. Different societies differ here, but prominent options include the following: a division of power between institutions, designed to get them to serve as checks-and-balances on each other; efforts to keep the overall size of the total set of such institutions under control; and a system of democratic entitlements, allowing people to vote for and against those people with ambitions to run social institutions.

\section{Content}

We have drifted into the content of a sound human rights education already, which should come as no surprise, given the well-known difficulties of firmly separating form from content in the first place. The aim in this section is to diagnose some of the hottest topics in North American human rights education and to urge a principled stand on various prickly dilemmas often highlighted in university class - a stand which preserves a coherent commitment to the universality, reasonableness and equality which are part-and-parcel of the human rights idea.

\subsection{Hot Topics}

Even though the latest human rights theory rightly pours cold water over the supposed distinction between first- and second-generation rights, it is still commonly encountered. Some have even discerned a "third-generation" of human rights claims. This generation does not have much conceptual coherence to it - the way socio-economic issues dominate the second-generation - but it does possess a rough chronological sameness. Essentially, third-generation rights are those claimed post-1960. Now, there is no consensus whether third-generation claims are in fact human rights - indeed, 
even second-generation claims remain controversial, especially in America. Such "third wave" claims are, nevertheless, hot stuff, and they commonly include: a clean environment (especially breathable air and potable water); privacy (in the "information age"); cultural rights (usually to state support for minority languages and cultural diversity celebration); parental leave options and/or benefits; and vague yet real claims involving human rights protection in biomedical procedures and research (consider the current stem-cell debate, pitting in some circles pro-lifers against the seriously ill).

Two huge first-generation issues persist, too: security (emphatically in the United States post 9-11); and equality (particularly the connection between gender, sexual orientation and visible minorities on the one hand and, on the other, issues like marriage and educational and career opportunities) A big difference in hot topics, between North America and Europe, is that in the latter the connection between human rights and immigration-, refugee- and citizenship issues is robust, whereas in North America it barely registers. And a big difference between North America and Latin America is that issues of economic development and wealth disparity are not, in the former, tied to human rights the way they commonly are in the latter. Indeed, socio-economic rights claims are still under suspicion in North America, in spite of all its wealth and welfare state programs. Even in Canada, e.g., there is currently a case in front of the Supreme Court asking whether health care is a basic human right which Canadians can claim against their government. ${ }^{16}$ This suspicion, or hesitancy, about second-generation rights contrasts with Europe where - although they still worry about cost and mode of provision - there is a much larger consensus in favour of the universal provision of such entitlements. And America in particular differs from all the above countries with its current pitched debate on the exact balance between liberty and security in the wake of 9-11, and the controversial civil liberties legislation - The Patriot Act - which followed. ${ }^{17}$ Though Spain has recently had to consider such issues as well - in the wake of the March 11, 2004 train bombings - its government has not had to answer, the way America's has, strong questions about the status of thousands of captives in Afghanistan, Cuba, Iraq and Pakistan and how a society which cares about human rights should treat them. ${ }^{18}$

\subsection{Classroom Dilemma on Relativism and Tolerance}

It is important not only to know the hot human rights topics, and the modalities of human rights education. What follows to the end is an argumentative guide - or provocation? - to fellow human rights educators on common advanced-level classroom challenges to human rights. The first is this: I do not know about Europe or Latin America, but in North America there is a widespread moral relativism subscribed to by students. Some students even seem to think relativism and human rights go hand-in-hand. In particular, young North Americans are very keen on inclusiveness. Inclusiveness is indeed an important value, as are pluralism and tolerance. Defenders of human rights should believe them all. But it is wrong to do so on the grounds of moral relativism, which is what too many young people believe. Moral relativism is here the doctrine that there is no authoritative inter-personal, much less "objective", set of moral values. Ethics, rather, is radically intra-personal, profoundly subjective. It is the realm of opi- 
nion only - and good thing, too, since then we will not think we are "right" and try to force other people to obey us in a classically intolerant, authoritarian manner. This growth in relativism is a dangerous trend which human rights educators should resist. Why?

First, relativism is conceptually incoherent. The very essence of morality - the whole point of the practice - is to create rules or standards of conduct binding on all, so that social existence is both possible and improved for everyone. Hence all those rules about the wrongness of murder, cruelty, exploitation and deception, and all the others praising kindness, autonomy, honesty and the promotion of happiness. Devising such social standards is not possible if everyone is allowed their own radically personal interpretation of them, free of criticism and punishment. Ethical anarchism is not reasonable - it violates the rational end sought after by morality, which is the co-ordination of behaviour for the benefit of all. ${ }^{19}$

Second, relativism is wishful thinking. It expresses an irresponsible desire not to be accountable for one's beliefs or for one's actions and their consequences. If relativism is true, then no one is accountable - provided only they themselves endorse their own actions. This comforting convenience surely explains part of relativism's powerful psychological pull. But seductiveness does not a good argument make.

While relativism does lead to value pluralism - since different people will have different moral beliefs - it does not lead to respect for value pluralism, much less to tolerance. Consider this: if I have my own radically subjective moral beliefs, and part of my beliefs condemn another person as evil, then what about relativism requires me to "celebrate our ethical differences" or to treat that person with tolerance? The answer is nothing - and the fearsome flipside of this relativism is that no one would be justified in saying I am wrong, or in punishing me, if I decided to treat this "evil" person with rights-violating brutality. If I believe in being brutal, you cannot say that I am wrong and still be a relativist. All you can say is that you do not like it. But that is hardly a reason for me to stop; you might as well tell me you prefer to say "to-may-to" while I stick with "to-mah-to." So the tolerance engendered by relativism leads to tolerating the intolerant, and that is incoherent as well as socially disastrous. It underlines the conceptual and practical inconsistency of relativism. If you believe that something is morally right, you must believe that it is right for everyone, or at least for everyone else in the same circumstances. More importantly, if you believe something is morally wrong, you must think it is wrong not merely for you but for anyone else similarly situated. Again, that is because the very practice of morality is to construct social norms of conduct.

This is not at all to deny that we should have pluralism and tolerance. It is, rather, to illustrate their proper basis. Since it is incoherent to tolerate the intolerant, we realize that tolerance, to be meaningful and praise-worthy, must have its limits. Where should we locate these limits? I suggest precisely at the point where human rights become violated. We can and should tolerate pluralism of beliefs and practices which do not violate human rights - the very values of personal freedom, equality and even social recognition imply this. But as soon as the belief or practice threatens to violate human rights, it must be met with criticism, resistance and punishment. Human rights, as Rawls says, 
are at the baseline of morality and justice in our era. ${ }^{20}$ Owing to the universal importance of what they protect - i.e. everyone has an equal stake in their realization human rights serve as the objective (or, at least, globally inter-subjective) foundation for ethics, morality and law. They anchor the modern moral universe, and they must be realized.

\subsection{Classroom Dilemma: Universality or Western Bias?}

Critical students allege that human rights, in spite of the rhetoric about universality and equality, are in fact pieces of Western liberal democratic ideology which are not applicable to societies with non-Western and undemocratic political structures. Human rights also enshrine a degree of individualism that simply is not shared by some cultures, where social belongingness and group success rank higher in concern. The fact that ideas about human rights originated in Western Europe, they say, is not merely an accident: it is an important fact about the world-view contained in the human rights idea. This idea bears the indelible stamp of a European, or European-derived, culture and it is naïve at best, and arrogant at worst, to assume that this culture speaks to everyone, or is applicable to every existing social context regardless of local history. If human rights express what Western people believe should be provided to everyone in their culture, as a matter of minimally decent treatment, then that is wonderful and so be it. But, these critics ask, who are Westerners to insist that the idea also expresses an equal commitment to such treatment in every other culture? This is just the latest idea, and accompanying set of institutions, in a long history of the same old thing: arrogant Westerners using their power advantages over other cultures to re-make the world in their own image. Relatedly, smart critical students claim that it is no accident that human rights have risen to such special prominence in the period following the Second World War. For that period has been dominated, internationally, by the United States, and America has had a bedrock commitment to the idea of natural or human rights dating back to the first days of its own revolutionary origins. Whether by design or sheer dint of its power, America has put human rights front and centre. In doing so, it has availed itself of the rhetoric of universal truth and betterment but, in reality, it is simply doing what all dominant powers in history have always done: re-make the world in its own image, and assure the world it looks all the more beautiful as a result. This is, skeptics say, more a matter of extending the security, comfort and power of the dominant civilization than it is of genuinely bettering the welfare of all humanity. ${ }^{21}$

Any effective response to this accusation of Eurocentrism, or more accurately Western bias, must start off by acknowledging the mixed record of the history of Western involvement with non-Western cultures. Some sensitivity must be shown to this fact. It is also probably true to point out that American hegemony has been one of the reasons for the sharp rise in the prominence of human rights in the past fifty or so years. One wonders whether human rights would be so influential had history taken another course and a different power came to enjoy global primacy. All these admissions, however, are not devastating to the principled human rights defender.

Such a defender could, at this point, raise caution about the so-called "genetic fallacy." The genetic fallacy refers to a flaw in reasoning. The flaw here is this: rejecting an 
argument, or theory, not on the basis of its own merits but, rather, on the basis of the irrelevant personal characteristics of the person or group who invented it. Perhaps the most notorious real-world example of the genetic fallacy occurred in Nazi Germany, when it was briefly official policy to reject the theory of relativity because it was devised by a Jew, Albert Einstein. This is, obviously, an instance of poor reasoning, since the personal characteristics of Albert Einstein have no relevant bearing whatsoever on whether the theory of relativity he invented offers a true account of time, space and the movement of physical objects in the universe. Similarly, we might say that, from the fact that the idea of human rights was probably first devised in Western European culture, it does not follow that the idea is therefore limited in application only to that part of the world. The criticism of Eurocentrism, as a criticism of human rights, errs because it does not deal with the merits of the human rights idea itself but, rather, with the characteristics of the people and civilization out of which it first came. The Eurocentrism criticism offers no conspicuous criticism of the moral merits of realizing human rights, and as such misses the mark. It throws the baby out with the bathwater. Furthermore, from the fact that the human rights idea originated in Western Europe, it does not follow that Western European culture is thereby revealed to be a blessed, and utterly superior, cultural form. Good ideas come from all over the place, and wisdom consists in knowing when to adopt a good idea and make it one's own, as opposed to refusing to do so out of a misplaced stubborn pride. Just because the good idea of human rights came out of Western European culture does not mean other cultures should resist it, any more than it denotes the sheer supremacy of Western culture. After all, some of the most grievous and appalling human rights violations have occurred right in the very heart of Europe.

The human rights defender can also point out that the criticism of universality is often put forward (outside the class) in bad faith. It is surely no coincidence that this criticism is most prominently made by governments in countries with poor human rights records. Such governments - that of China being one of the most forceful have every self-interested reason to denounce human rights, since the realization of human rights in their countries would challenge their own power, perhaps resulting in institutional transformation. One of the most effective means of denunciation in such countries is often to link it to anti-Western biases. The result is a bogus denunciation of human rights, since it is not on their own merits but on the back of official propaganda that manipulates popular prejudices for the gain of a small cadre of politicians thinking only about themselves. When officials in repressive and rights violative societies criticize human rights as alien to their culture, we can reply by asking what makes such officials the authority on declaring what is, and is not, part of their culture? One presumes, for example, that opponents of such officials - e.g. political dissidents languishing in jail - would not acknowledge the right of such officials to speak for them about the desire for human rights in their culture. Against the cost of being accused of being arrogantly Eurocentric, human rights defenders have to measure the larger cost of abandoning those courageous activists committed to realizing pro-rights changes in the face of repressive regimes. Fundamentally, it is not arrogant to presuppose that everybody wants to be treated decently; it is arrogant to suggest that some people do 
not have such wants, and thus are not entitled to live in a minimally just social and political context.

The sceptical student's claim, that significant chunks of humanity do not endorse human rights, also runs afoul of the evidence in favour of cross-cultural consensus on the propriety of human rights and the desirability of what they are designed to protect. How are the skeptics to explain the fact that nearly every country in the world has joined the United Nations, and that the Charter of that organization commits all its members, among other things, to respect human rights? How to explain the fact that the overwhelming majority of countries have ratified various international human rights treaties, the most important of which being the International Bill of Rights, composed of the Universal Declaration and the two subsequent International Covenants? How to account for the fact that, within their own national constitutions, a great number of non-Western countries confer to individual citizens civil rights which are consonant with the human rights we are concerned with? It may interest readers to know that many non-Western countries, in addition to the above activities, have devised their own articulation of what human rights mean within their own cultural traditions. There is, for example, the African/Banjul Charter on Human and People's Rights (1981) and the Cairo Declaration on Human Rights in Islam (1990). These international treaties contain substantially the same core ideas about the need for minimally decent treatment of human beings as the supposedly "Western" understanding. Of course, such treaties include references and emphases not found in other documents - e.g., to Allah in the Cairo document - but they are not inconsistent with the elemental moral vision contained within the very idea and within other documents. Indeed, there are various treaties amongst Western countries themselves which do the same, adding nuances to the core idea for application to their own neck of the woods. Examples include the European Convention on Human Rights (1953), the InterAmerican Convention on Human Rights (1969) and the Charter of Paris for a New Europe (1990). ${ }^{22}$

This cross-cultural consensus comes as no surprise, since the human rights idea is so thin and minimal, so elemental and fundamental to people's understanding of how a person ought minimally to be treated. Most of the world's moral traditions contain the idea that the human person has worth, and there is recognizable overlap between traditions regarding basic ethical propositions, such as the wrongness of murder and the desirability of forwarding human happiness. The minimal and baseline nature of human rights protection blunts much of the sharpness from the skeptic's accusations regarding Western arrogance, and associated intolerance of difference. Human rights are not the be-all and end-all of moral and political debate: there is much to ethical life that is not captured in them. Thus, respecting human rights does not demand the utter sacrifice of one's own unique cultural traditions and peculiarities. There is much room above the minimal threshold for cultural difference, ethical pluralism, and the maintenance and enhancement of unique customs and traditions.

So promoting human rights is not the same thing as promoting the Western, or American, way of life. Promoting human rights is about establishing everywhere the moral, legal and political protections designed to allow everyone the opportunity not 
just to live but to lead a minimally decent life - a life worthy of a human being. It is true that the logic of human rights demands the sacrifice of those practices which attack that value: it does set a limit on the degree of pluralism which reasonable people should tolerate. ${ }^{23}$ Like any other moral value with real substance, the human rights idea does draw a line, and specifies that crossing it subjects one to legitimate criticism, resistance and perhaps punishment. Human rights, after all, would be completely empty and devoid of function if they ruled nothing out.

The final argument for the human rights defender to appeal to, in this regard, refers to globalization. Like it or not, we now live in a world where there are clear and powerful connections between all peoples. These connections include international trade, diplomacy, military alliances, travel and tourism, educational exchanges, development aid, the transmission of media and culture both high and low, and so on. Indeed, there is even a robust set of international institutions, ranging from regional associations such as the European Union and the North American Free Trade Agreement - to genuinely global organizations, like the United Nations, the World Trade Organization, the International Court of Justice and the International Monetary Fund. This globalizing trend appears to be both widening and deepening: the world is drawing ever closer together. Now that our interconnections are genuinely international, we need - as the holistic basic structure approach suggests - core ground-rules to govern our interactions and our shared institutions. These ground-rules, at the very least, must make sense: they cannot permit the performance of contradictory practices. A relevant example of a pair of contradictory practices would be one which respects human rights, and one which violates them. The global community must decide on a consistent set of groundrules for everyone: we can no longer indulge contradictions like permitting rights violations abroad but insisting on rights realization at home. The one set of international institutions demands one set of coherent, plausible and defensible ground-rules. I suggest that such ground-rules importantly involve human rights. Human rights not only have their own moral force but also attract cross-cultural consensus. They are thin and minimal yet still vital and substantive. They establish core values, yet still allow for some cultural pluralism. They fit the bill perfectly for inclusion in that set of groundrules needed to forge further a developing international society. ${ }^{24}$

\subsection{Classroom Dilemma: Human Rights and Social Disruption}

We turn now from controversy surrounding the universality of human rights to those surrounding their consequences. A major criticism, under this heading, is the accusation that human rights disrupt social cohesion, since they express and reward selfish and antisocial attitudes. The image of the rights-holder these critics share is very much like the picture of the character Shylock in Shakespeare's play, The Merchant of Venice: greedy, narrow-minded, self-centred, insensitive to others, insisting on getting his own pound of flesh even though he does not need it and regardless of the damage done to other people. More recently, Mary Ann Glendon has written that North America's contemporary obsession with "rights talk", in all its forms, has had the effect of diminishing both the width and depth of the common life we share. ${ }^{25}$ With each right we enumerate, we take something out of the realm of public policy and put it into the 
realm of private entitlement. Not surprisingly, this leads ordinary people to put most of their time and energy into forwarding and asserting their own rights claims, as opposed to tending, in a publicly-spirited way, towards the common good. Since rights-claiming necessarily involves individual assertion, this trend can only undermine people's skills at, and willingness to engage in, the development of such vital virtues as taking on responsibility, negotiating, and being willing to make reasonable compromises so that progress can be made on public policy issues. Rights talk, critics fear, has this disturbing tendency to crowd other issues out of the limelight, forcing them backstage. But since rights do not capture everything important in moral and political life - something we just admitted at the end of last section - it follows that political discourse and social action are impoverished by rights, whether human or more specialized. More concretely, there is a clear sense, in some of the pro-security legislation passed world-wide after 9-11 - and especially in America itself - that too much freedom and too little government control and supervision can be a dangerous thing. Human rights seem viewed by some officials as themselves sources of social disruption: creating instability, ill-feeling and perhaps paving the way for something much worse.

Communitarians, like Michael Sandel and Amitai Etzioni, ${ }^{26}$ have written eloquent testimonials about a collapse in public spiritedness since rights talk came to dominate political life. Their complaints are not simply nostalgic laments for a lost way of life: they are rooted as well in a fear that this phenomenon can only lead to more antisocial behaviour, brazen selfishness, and ultimately fragmentation and conflict. Over time, rights rupture: they tear apart a shared sense of public life and the common good, finally leaving every man and woman to fend for themselves. What the idea of the rights-holder does, above all, is shove to the side the idea of the good citizen. Instead of the ethics of rights, the politics of atomistic individualism and stubborn insistence on selfish entitlements, they say we need the ethics of the good citizen, the politics of the common good, and a willingness to compromise one's claims out of public spirit and with an eye towards preserving a life rich with community feeling and interconnecting support structure. Some government types would add that, if we did this, we would have more peace and security to boot.

This is an interesting criticism, and it resonates with some students, but it ultimately fails to persuade. For example, it is deeply unclear whether the rise in rights talk has actually caused a collapse in public spiritedness, or rather whether such a collapse was brought about by something else, and that an ethic of rights simply speaks more accurately and honestly to the aspirations of our age. It seems to me that, to the extent to which the common ground has shrunk, that has been because of major shifts in social structures, and not because of the supposedly corrosive individualism of the rights idea. Some closely-knit communities have indeed been ruptured and transformed by emigration and immigration, by technological innovations (especially in communications) and by changes in the economy which stress the value of mobility and the development of a skill set which is saleable worldwide. These social shifts have mixed people of different backgrounds like never before. The differences in their beliefs and values have put pressure on political structures to pay less attention to preserving a traditional way of life and more attention to ensuring basic fairness for all. Rights, far 
from rupturing, actually fill in a moral gap left behind by the collapse of traditional "community values." Rights are actually a more appropriate and plausible candidate to dominate moral and political life in our time, because they reflect, better than any of their competitors, the salient aspects of life in the modern world. As the world becomes more globally interconnected, we can actually predict with some confidence a further rise in rights talk. This trend is for the better, because it shifts public discourse away from bitter controversies regarding whose traditions should prevail towards a more neutral set of concerns regarding equal entitlements for all regardless of background.

This is to say that an emphasis on rights may actually help to smooth over political ruptures, as opposed to provoking or even creating them. The idea that rights, including human rights, are essentially selfish and antisocial fails to carry with it the stamp of necessity. Sure, there are selfish people out there who only care about their own private concerns, and the rest of the world be damned. Some people really do seem to use their rights in a Shylockean, belligerently self-assertive way. They treat their rights like sticks to beat back the rest of the world, preventing it from horning in on their own personal universe. But that is more a matter of such people's own psychological shortcomings than it is a legitimate criticism of the very idea of rights. Consider the fact that rights necessarily presuppose a social context. Rights were not invented so that modern man could fancy himself a rock, or an island. They were invented to try and ensure elemental fairness between people living together in society. An emphasis on rights necessarily comes hand-in-hand with an emphasis on responsibilities. Rights can only be made real when relevant others and institutions behave appropriately. So there is not the one-sidedness alleged by rights critics. Furthermore, the idea of human rights especially seems as much a wonderful affirmation of social solidarity as it does a glorification of the individual person. It is true that human rights are rights individuals have, but all individuals get to have them: membership in the human rights club is much more socially inclusive than membership in any other kind of moral or political community. How can that be consistent with selfishness? The institutions demanded by human rights thus actually seem to be an expression of values shared between people, as opposed to those that tear them apart. We ought never to overlook the minimalism of human rights in this regard, realizing that such a focus on ensuring a baseline of decent treatment for all still leaves communities with plenty of room to preserve local customs, traditions, and ways of life.

Finally, if respect for rights supposedly generates fragmentation and conflict, try on the other hand the violation of rights. I suppose it is true to say that any moral idea of genuine substance and worth is going to generate some controversy. Fine, but what is the alternative? Against the risk that some people will use their rights as an excuse to opt out of social togetherness, we have to weigh the much more serious risk of not enshrining respect for human rights at all. That risk, we know from history, would not only involve actual rights violations but also - through them - the production of division and conflict, resistance and violence. The violation of human rights is much more damaging and divisive than the respect for them ever could be.

As for the supposed trade-off between liberty and security, there are real issues of reasonable public safety to attend to in light of contemporary terrorism. But, concep- 
tually, it is a matter of wrestling over what our rights to security and freedom really mean, not of determining which one is in and which one is out - much less of asserting that human rights and civil liberties undermine national security. Security and liberty are both human rights, and we must work through a consistent idea of how we require both, and structure our institutions accordingly. This only underlines the importance of the holistic approach so recently stressed in the human rights literature.

\subsection{Classroom Dilemma: Post-Modernism and Justifying Human Rights}

Let's end by returning to the themes at the start of this section. North American students are attracted not only by relativism but post-modernism, too. These ideas have much in common, and the latter should be rejected as handily as the former, especially when connected to the justification of human rights. An influential post-modern philosopher, Richard Rorty, has wondered whether we need to justify human rights i.e., to demonstrate their moral correctness - at all. ${ }^{27}$ Rorty views the debate over different kinds of justification - always controversial in class - as one of endless dispute and debate, a futile quest for The One True Argument establishing human rights. Rorty believes that we can do very little by way of reasoned argument to change the beliefs and behaviour of a hard-hearted human rights-violator. "(I)t is of no use whatever", he submits, "to say [to such a person]...(n)otice that what you have in common, your humanity, is more important than these trivial differences", such as race, religion, gender, ethnicity, or national citizenship. Providing philosophical justifications for human rights is far less important than - perhaps even useless in comparison with - developing in people an emotional disposition in favour of respecting people's human rights. Rorty thus extols the virtues of providing "a sentimental education", exposing people to the realities of life of those who are different from them, with the aim of "manipulating their sentiments" in line with respect for human rights. In Rorty's judgment, things like literature and film, along with journalism and television, are much more adept at achieving this aim than the abstract and general arguments of law, political theory and philosophy. An immediate, personal and emotional identification with others is the most effective inducement against violating their human rights, and is much more potent than trying to get someone to follow a chain of reasoning which moves from controversial premises to contentious conclusions.

This is not to say that Rorty disapproves of the human rights movement, and the prevalence of human rights culture throughout many parts of the world. He indeed favours the creation of what he calls "an Enlightenment utopia" - i.e., a liberal democracy which is rights-respecting and humane, secure and secular, prosperous and committed to the general welfare in terms of key social goods like education and health care. His point is that a world filled with Enlightenment utopias is more likely to be brought into being through the effects of sentimental education rather than through argumentation and reasoning: "Producing generations of nice, tolerant, well-off, secure, other-respecting students of this sort in all parts of the world is just what is needed indeed all that is needed [his italics] - to achieve an Enlightenment utopia. ${ }^{28}$

Rorty is probably correct to suggest that, often, reasonable argument is not as effective at changing people's beliefs and behaviours as we might wish it to be. We can think 
of many other motives and drives, other incentives and stimuli, which seem to get people "going" much more readily than a sensible justification. Things like fear, greed, lust, envy, resentment, the desire for power, and so on, clearly play a large role in human behaviour. But what we are seeking here is more a sense of how we should act, as opposed to how we actually act, sometimes to our regret. Just because we are often moved more immediately, and forcefully, by sensory stimuli and emotional reactions does not imply that we should give in to them utterly, and base our mutual dealings with each other on them, and them alone. Social institutions cannot be run on sentimentality: there does need to be a core commitment to human decency and respectful treatment, of course, but needed as well is a lot of rational planning with regard to institutional design, the allocation of resources, measuring the effectiveness of expenditures, devising procedures for reform and change, and so on. This is especially true when speaking of far-flung regional or even global institutions.

Rorty underestimates the degree to which we can be responsive to a reasonable justification, and overestimates the degree to which we can be manipulated according to our sentimental dispositions. When we are confronted with a reasonable justification for a claim, whether it be in science, political science or daily life, our beliefs often do change, albeit usually with further consideration. When they do change as a result of such confrontation, such change is often more enduring in its effect on our behaviour than when we act on the basis of emotion and sentiment. ${ }^{29}$ Sentiment shifts, often with shocking and senseless rapidity, whereas the conclusions of a reasonable justification endure. Rorty is right to suggest that we often resist changes in our beliefs much more than we resist changes in our emotions. But change our beliefs we do, especially when confronted time and again with the force of a well-grounded claim made with insight and clarity. Sound systems of education are a standing testimony to this reality. So if we could change the beliefs of someone disrespectful of human rights, it would follow that we could have a much more enduring social shift than if we merely manipulate their passions through tender tutoring in the sensitive arts - a pedagogical process, one of my students noted, which seems surprisingly close to plain old propaganda. And who is to say we will succeed with such emotional manipulation?

Some people - especially human rights-violators - are hard-hearted, and utterly lack a social conscience. Often, such people are beyond the reach of emotional appeals: they are cold and callous, dissociated from other human beings. They are often openly contemptuous, even hate-filled, towards their victims. ${ }^{30}$ Is making them watch Schindler's List, or making them read a biography of Nelson Mandela, going to move them? Hopefully, yes, but there are no guarantees of that: such a strategy assumes a degree of moral maturity that may not be there. Does reasoning with them offer greater prospects? I believe so, because such people often remain rational in spite of the decrepitude of their character. If they can be persuaded that they act on the basis of incorrect assumptions, or faulty inferences, or in violation of principles they themselves believe in, then they may be more open to reconsider and reform than if they are simply hectored at for not being sensitive enough. Often, reformed criminals speak soberly about society's justification for jailing them and subjecting them to force: they speak much more in those terms than in terms of identifying with, and being sensitive 
to, their victims. But there are, admittedly, no guarantees with reason either: that is why it is ultimately the use of force, and the threat of coercive punishment and rectification, which stands as the most effective and reliable guarantee against human rights violation. When human rights violators fail to respond to other appeals, we respond with force, and rightfully so. Rights, to be real, need to be enforced.

This is not to say, to amend Mao's phrase, that human rights flow from the barrel of a gun. They do not: human rights can be more effectively secured if they are enforced, but such enforcement is not what justifies their existence. What justifies the existence of human rights is not force, nor sentimentality, but rather a compelling set of reasons to treat human beings in a minimally decent fashion. Indeed, it is the importance of such reasons, and the principles they stand for, which justify the resort to force in attempt to secure them from merciless predators, either in the form of individual criminals or unjust social institutions. Which reasons are these?

I support a plural strategy for justifying human rights, as opposed to putting all one's eggs in one basket. Different people can support human rights for a variety of reasons, and that there is probably more than one good reason which provides powerful support for the existence of human rights and the force of their claim on our behaviour. Though these reasons can only be mentioned and not here fully explained - as I have tried elsewhere ${ }^{31}$ - they include: 1) self-interest, since the objects of human rights are those we all vitally need to both live and to pursue our vision of a good life; 2) the value of fairness, since we realize everyone else needs the objects of human rights as much as we do, and we want reciprocity from them; 3) the elemental moral duty of not harming people in connection with their vital needs; and 4) the interest everyone shares in living in a happier and more stable society.

The deep irony with Rorty is that, in the final analysis, he too sports a justification for human rights. In spite of all his post-modern protestations regarding the limits of reason, and how we do not need a rational foundation for our human rights claims, it is crystal clear that he offers us an important rationale for supporting human rights: such support contributes to the development of an Enlightenment utopia. This is an example of a consequentialist justification for human rights: we should believe human rights exist, and act accordingly, because if we do so society will be improved as a result. We will enjoy the fruits of living in a more pleasant, stable and successful society if we respect human rights than if we fail to do so. Rorty might even offer as evidence a historical comparison, in quality and enjoyment of life, between societies that have respected human rights and those which have not. This is actually a quite compelling and reasonable justification, so it is surprising that Rorty does his level best to suggest there is no need for such justification at all. The reason he does so, upon reflection, becomes clear: since he assumes the superiority of one form of justification all along, he assumes there is no further need to pursue the question. He believes he has the right answer, so he find the question uninteresting. While we might agree with the strength of his consequentialist form of justification, it seems rather disingenuous for Rorty to pretend that he is not involved in offering a justification at all, or that he is somehow above that, or doing something different altogether. He is not above it: he is in the 
very thick of the controversy surrounding justification, as any strong defender of human rights must be. Students cannot, on the glamorous authority of any post-modernist, shirk responsibility for considering which values justify human rights and why.

\section{Conclusion}

This paper had two parts: to survey the modalities and hot topics in North American human rights education; and to offer informed arguments of substantial use to human rights educators in the face of common philosophical challenges. In the course of these reflections, the following propositions were established:

1) there is an issue of access to advanced human rights education in North America;

2) North American human rights education is too inward, failing to confront fully international human rights and issues of duties of the rich toward the global poor;

3) Relatedly, North American human rights education is too focussed on domestic civil liberties legislation;

4) A pedagogy revolving around understanding the basic structure might cure this legal obsession, and also disabuse students of stale distinctions between first- and second-generation rights;

5) The latest research stresses holism between human rights and their associated institutions, not just nationally but internationally in light of globalization;

6) We have the conceptual resources to counteract students' mistaken attraction to ethical and political relativism and post-modernism; and

7) We have powerful arguments underlining the genuine universality and rationality of human rights, and undermining those who suspect human rights cause problems for national security and social cohesion.

\section{Notes}

1. Human Rights Education Associates, <www.hrea.org>.

2. Ibid. See also the Human Rights Research and Education Centre, <www.cdphrc.ottawa.ca>.

3. See the Canadian International Development Agency <www.cida.ca $>$ and the United States Agency for International Development <www.usaid.gov>.

4. See Amnesty International <www.amnesty.org > and Human Rights Watch $<w w w . h r w . o r g>$, for instance. There are many more: some charge for this service, others volunteer.

5. See the Social Sciences and Humanities Research Council of Canada <www.sshrc.ca $>$ and the National Endowment for the Humanities <ww.neh.gov>.

6. T. Pogge, World Poverty and Human Rights: Cosmopolitan Responsibilities and Reforms (Cambridge: Polity, 2002).

7. For more on definitions, see Brian Orend, Human Rights: Concept and Context (Peterborough, ONT: Broadview, 2002), 15-36.

8. Orend, Human Rights, 101-29.

9. Some of the socio-economic rights listed in the UDHR seem too boldly expressed, however. But I do strongly support the idea that we can make substantive socio-economic claims as a matter of human right. We do have the human right to material subsistence: it's 
obviously a vital human need. The controversial issue deals with what we can reasonably demand in connection with this vital need. I look at this perplexity at Orend, Human Rights, 129-55 and B. Orend, "Justifying Socio-Economic Rights", in R. HowardHassman and C. Welch, eds. Sleeping Under Bridges: Economics Rights in Canada and the United States (Forthcoming 2005, Georgetown University Press).

10. J. Rawls, A Theory of Justice (Cambridge, MA: Harvard University Press, 1971); J. Rawls, "The Basic Structure as Subject" in A. Goldman and J. Kim, eds. Values and Morals (Dordrecht: Reidel, 1978), 30-48; and T. Pogge, Realizing Rawls (Ithaca, NY: Cornell University Press, 1989.

11. Pogge, Rawls, 28-9.

12. Amartya Sen, Development as Freedom. New York: Anchor, 2000; and H. de Soto, The Mystery of Capital (New York: Basic Books, 2000).

13. Orend, Human Rights, 24-31. See the International Covenant on Civil and Political Rights and the International Covenant on Economic, Social and Cultural Rights. These binding international treaties came into force in 1976, and most countries have ratified them. The Bush Jr. Administration has recently "unsigned" America's commitment to the latter. For the full texts, see the United Nations' High Commissioner for Human Rights, $<$ www.unhchr.ch>.

14. See also H. Shue, Basic Rights (Princeton, NJ: Princeton University Press, 2nd ed., 1996).

15. See also M. Ignatieff, The Rights Revolution (Toronto: Anansi, 2000) and N. Ferguson, Empire (New York: Basic, 2002).

16. The plaintiffs include George Zeliotis and Jacques Chaouilli.

17. Consult the Department of Homeland Security, at <www.dhs.gov>, for the text and rationale of the Act. See also R. Leone and G. Anrig, The War On Our Freedoms (New York: Public Affairs, 2003). For an analysis of Canada's equivalent legislation, see R.J. Daniels, et al, eds. The Security of Freedom (Tor0nto: University of Toronto Press, 2001).

18. These hot issues refer, in the main, to the treatment of Iraqi prisoners at the abu-Ghraib prison as well as the suspected terrorists detained in Guantanamo Bay, Cuba. On the latter, see R. Dworkin, "What the Court Really Said”, New York Review of Books, August 12, 2004, pp. 26-9.

19. J. Narveson, Respecting Persons in Theory and Practice (Lanham, MD: Rowman \& Littlefield, 2002).

20. J. Rawls, The Law of Peoples (Cambridge, MA: Harvard University Press, 1999).

21. A. Pollis and P. Schwab, eds. Human Rights: Cultural and Ideological Perspectives. New York: Praeger, 1979; T. Dunne, ed., Human Rights in Global Politics. Cambridge: Cambridge University Press, 1999; and T. Evans, U.S. Hegemony and The Project of Universal Human Rights. New York: St. Martin's, 1996.

22. H. Steiner and P. Alston, International Human Rights in Context: Law, Politics, Morals. Oxford: Oxford University Press, 2nd edition, 2000.

23. J. Rawls, The Law of Peoples. Cambridge, MA: Harvard University Press, 1999. Pp. 78-82.

24. T. Pogge, “The International Significance of Human Rights", Journal of Ethics (2000), 45-69.

25. M.A. Glendon, Rights Talk: The Impoverishment of Political Discourse. New York: Free Press, 1991.

26. M. Sandel, Liberalism and The Limits of Justice. Cambridge: Cambridge University Press, 1982; and A. Etzioni, The Spirit of Community. New York: Touchstone, 1994.

27. R. Rorty, "Human Rights, Rationality and Sentimentality", in S. Shute and S. Hurley, eds. On Human Rights. New York: Basic Books, 1993.

28. R. Rorty, Contingency, Irony and Solidarity. Cambridge: Cambridge University Press, 1989.

29. P. Thagard, Mind (Cambridge, MA: MIT Press, 3rd ed., 2000), 139-55.

30. The United States Department of Justice, at <www.doj.gov> searching under "recidivism."

31. Orend, Human Rights, 37-100. 